\title{
An Article Review on "The Use of Politeness Strategies in the Classroom Context by English University Students"
}

\author{
Rohandi Yusuf ${ }^{1}$ and Anwar ${ }^{2}$ \\ ${ }^{1}$ Al-Wathaniyah Junior High School, Perawang, Indonesia \\ ${ }^{2}$ Vocational High School 7, Pekanbaru, Indonesia \\ yusufrohandi45@gmail.com
}

\author{
ARTICLE HISTORY \\ Received : 10 May 2019 \\ Revised : 25 May 2019 \\ Accepted : 1 June 2019

\section{KEYWORDS \\ Politeness Theory \\ Politeness Strategies \\ English Classroom \\ English Language Teaching \\ University Students}

\begin{abstract}
This study aims to review and look at politeness strategies in the Classroom Context by English University Students. Politeness in English language teaching is still a major concern. This is considered a way of ensuring positive contact in the classroom. As an essential actor in the class, teachers and students must also cultivate politeness as a way to establish positive engagement in the classroom. In order to investigate the politeness phenomenon in EFL interaction, the researchers applied a descriptive qualitative research method. Two sections of English literature were included in this research. The key data sources were the individual student presentations recorded. The recording took fifty transcripts, which lasted between five and seven minutes for each performance. The transcripts were examined and debated on the basis of Brown \& Levinson's theory of politeness. The findings of this research indicate that English students used different types of words to express their courtesy within the classroom. Such phrases were in the form of greetings, thanks, apologies and fillers. Some terms were also taken from the vernacular language of students who acted as a tool to soften their presentation. Such words were marked as positive and negative politeness. The results of this study could be used as a means of establishing effective interaction between teachers and students in the classroom.
\end{abstract}

\section{Introduction}

To create effective classroom interactions, the teacher and students will rely a lot on their communication. Teachers and students use language for both verbal and non-verbal communication. Consequently, they must adopt an effective communication plan to clearly articulate their ideas. Several studies show that teachers and students need class approaches to express their ideas. Teachers and students as major players in class interactions connect with each other in different styles. To interact, people should be careful not only to complete the information but also to move it in a way. Effective communication not only aims to successfully transmit messages, but also to create comfortable communication between partners that can create solidarity and intimacy. With the implementation of a politeness approach, this effective communication can be achieved. The study of politeness in communication.

First illuminated by Brown \& Levinson (1987) with the idea of "face-saving views", the issue of politeness has been explored further in many different languages and contexts. Holtgraves \& Perdew (2016), for example, study the relationship of politeness with uncertainty. Another recent study on this problem is by Sukarno (2018) who studies politeness in relation to the use of demand. All of this research proves that politeness has an important role in communication. The issue of modesty doesn't just attract attention bachelor in sociolinguistics and anthropolinguistics as described above. Other communication arrangements, such as education and classroom settings, also highlight the important role of politeness. Jiang (2010) claims that in the context of language teaching, politeness is believed to enhance learning by providing a lively and friendly atmosphere in the classroom. Payne-Woolridge's (2010) study had focused on facework in the classroom, which in fact can become an alternative to introduce a fresh way of considering the way teachers speak to pupils about behavior. Findings of these studies confirm that politeness is important in the classroom interaction. Maintaining politeness in the class is a good strategy to reach effective classroom interaction. Mahmud (2018) had explored the English students' perspectives on politeness; however, the focus was not on the strategies of politeness. It focused only on the English students' perception of how to be polite in the class. Politeness studies which explore deeply about the English students' strategies are still limited and therefore, need to be further explored.

Referring to this phenomenon, politeness strategies in class, especially by English students in teaching English, are still an important issue to be explored. Very little research has focused on the strategy of English students in expressing politeness, especially at universities. The context of studying the politeness proposed in this study brings a new phenomenon of politeness research. The 
communication context, class presentations among British students, becomes a potential area for observing politeness strategies and therefore, brings significant findings in politeness research, especially politeness studies in EFL classroom interactions.

The research then focuses on the use of politeness strategies by UK university students in the classroom context. The findings of this study are expected to contribute to the study of politeness in EFL classroom interactions. This might also serve as a useful input for practitioners of classroom interactions, especially English teachers and students to create effective EFL classroom interactions.

In the English classroom context, as seen in this report, even different forms of politics are found, such as the use of terminology influenced by Islamic teachings and the use of vernacular language influenced by the students ' cultural contexts. Many papers on politeness often show the various strategies used to describe politeness. For example, Senowarsito (2013) found some positive and negative political strategies in the classroom and all serve as a way to create characters. Zander (2013) also found other radical and impolitist views in the college. Attention to the lesson in the course is regarded as nice, while late class behavior is regarded as impolite. Such studies all suggest that politeness is important for the interactions of the EFL classroom, and therefore there are some strategies that English students can use to contribute to successful EFL interaction.

\subsection{Politeness}

The popular courtesy theory is the view of saving the face of Brown \& Levinson (1987). The central idea of this theory is the idea of face (Bargiela-Chiappini, 2003). Brown \& Levinson (1987, p. 62) state that face is "the public self-image that each member wants to claim for himself." Everyone wants to look after each other's faces, otherwise, Face Threatening Acts (FTAs) such as being offended, or disturbed can occur. Being polite means defending "face" and avoiding actions that threaten each other's "face".

Brown \& Levinson (1987) propose five politeness strategies. The first strategy is "to put it bluntly on the record without redressive action", which follows what it says. The speakers conducted the FTA in the most direct, clear and unambiguous way because they believed that there were times when some obstacles forced people to speak very directly. For example, if there is an emergency or if there are major time constraints where the speaker saves time to be effective. The second strategy is the "positive politeness strategy". This is a call for solidarity with others, namely how to make the listener feel good or make him think that his values are shared. Positive courtesy is used to expand intimacy, to imply equality or to share desires. The third strategy is the "negative politeness strategy" which refers to an effort to show awareness not to be forced, that is to avoid interfering with the other person's freedom of speech by using hedges and apologies among others.

Brown \& Levinson consider this strategy as the heart of appreciative behaviour because it performs the function of minimising coercion of the listener. The fourth strategy is "not recorded". In general, this is the use of utterances that are not directly addressed to others. This is called indirect speech. In this strategy, the speaker does an FTA by saying something indirectly (implicative).

\subsection{Face Threatening Act (FTA)}

According to Brown \& Levinson (1987), actions that threaten faces can threaten the speaker's face or the listener's face, and they can threaten positive faces or negative faces. The FTA or Face Threatening Act includes gratitude, apologies, promises, even non-verbal actions such as tripping, falling or any words that intrinsically threaten other people's faces (positive or negative). This also includes disagreements, criticisms, orders, sending bad news, and requests. For example, a simple request threatens the negative face of the target because the target's compliance with the request interferes with his desire to remain independent.

Conclusively, FTAs are actions that challenge the desires of other people's faces. Brown \& Levinson (1987) propose that when faced with the need to carry out FTAs, individuals must choose between conducting FTAs directly and efficiently or try to reduce the effects of FTAs on the positive/negative faces of the listener. Mitigation strategies are what Brown \& Levinson label as politeness strategies.

\subsection{Politeness Strategies}

Positive politeness strategies are displayed while the speaker asks for goals, and even establishes friendship through expression. The speaker makes himself preferred because he has a close friendship with the listener. It can also be said that positive politeness is a strategy of solidarity to make a closer relationship with the listener. For example, when one wants to ask someone to lend their pen, they'd ask politely with respect to borrow the pen.

Therefore, the founders of modesty have formulated modesty in five strategies according to the greater risk of FTA. The first strategy is to conduct an FTA without repressive or bald actions on records relating to minimal FTA. The second strategy is to carry out FTAs with repressive measures with positive politeness. Then, the third is negative politeness which aims to handle FTA at the middle level. The fourth is a record for handling high-level FTA. The latter is 'don't FTA' because of the higher risk. A series of possible strategies can be drawn up and explained in Figure 1.3.1. 


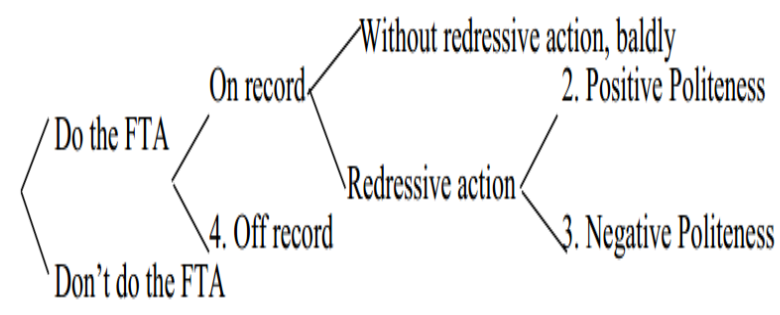

Figure 1.3.1 Possible Strategies for FTA

Furthermore, Brown \& Levinson list the possible strategies in the positive and negative politeness taxonomy. Table 1 shows 16 positive politeness strategies, 10 negative politeness strategies, 3 Off Record strategies, and 4 Bald on Records.

\section{Method}

Figure 2.1 illustrates clearly the steps that the authors undertook to conduct this article review.

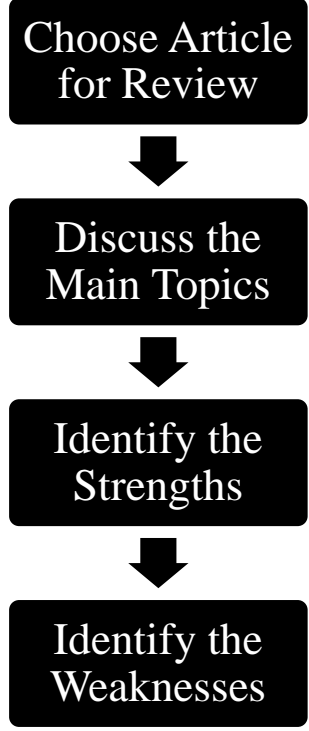

Figure 2.1 Flow of the Article Review

Figure 2.1 shows the method of that the authors use to conduct the article review. First, the authors have chosen the article meant for review, which is Mahmud's 2019 article entitled "The use of politeness strategies in the classroom context by English university students." This article is chosen based on the recommendation of the authors' supervisor. Second, the authors feel the need to discuss and elaborate the key concepts of the relevant article, which is about politeness theory. Third, the authors focus on the relevant article to identify the strengths and also, fourth, the weakness of the article. By fulfilling these four steps, the authors present their review of the article.

\section{Results}

This study presents the results of the article review from the research design, samples, analysis techniques, followed by strengths and weaknesses that the authors found in Mahmud (2019).

\subsection{Research Design of Mahmud (2019)}

Mahmud's (2019) research uses descriptive qualitative design. The article that this study reviews used comprehensive narrative and visual data collection, analysis, and interpretation to gain insight into certain interesting phenomena, namely the presence of politeness strategies employed by students. As a descriptive qualitative research design, the relevant article is intended to collect, analyse, and interpret some of the existing data related to one particular phenomenon, namely politeness strategies by students in classroom interactions. The relevant article was conducted at the level of an undergraduate program at one of the state universities in Makassar, Indonesia, in 2015.

\subsection{Participants of Mahmud (2019)}

The participants in the article this study reviews were fifty students who were selected purposively. They are students of the English Literature Program and take anthropolinguistic courses where students are assigned to give presentations on one anthropolinguistic case. Their presentations are recorded by students themselves using cell phones. They last for 5-10 minutes for each student. Class interactions where politeness can be observed are analysed.

\subsection{Data Analysis of Mahmud (2019)}

Data analysis is based on an analytical framework that relies on data re-recording, data transcription, data selection, and data interpretation. For this study, the analysis relies on fifty transcriptions of fifty students (each consisting of 3-4 pages). For a long time and many transcriptions, data were then selected based on the purpose of this study, based on content. The data is then interpreted and analysed in the form of a conversation extract. In extracting, relevant data are identified, discussed, and analysed to explore student politeness strategies based on the politeness strategy framework by Brown \& Levinson (1987).

\subsection{Strengths and Weaknesses of Mahmud (2019)}

Table 3.1 displays the strongest point of the article, which are the numerous identification of the politeness strategies used by students. 
Table 3.1 Politeness Strategies

\begin{tabular}{|c|c|c|}
\hline Features & Expressions & $\begin{array}{c}\text { Frequencies } \\
\text { of Utterances }\end{array}$ \\
\hline \multirow[t]{8}{*}{ Greetings } & Asssalamu $\quad$ Alaikum & 80 \\
\hline & $\begin{array}{l}\text { Warahmatullahi } \\
\text { Wabarakatu. }\end{array}$ & \\
\hline & Wa'alaikumsalam & 77 \\
\hline & Warahmatullahi & \\
\hline & Wabarakatu & \\
\hline & Good morning & 11 \\
\hline & How are you today? & 4 \\
\hline & Bismillahirrahmanirrahim & 6 \\
\hline Thanks & Thank you & 108 \\
\hline Address & Saudari/Saudari & 5 \\
\hline \multirow[t]{4}{*}{ Terms } & Names & 146 \\
\hline & Pronoun & 21 \\
\hline & Ma'am & 23 \\
\hline & Kak & 6 \\
\hline \multirow[t]{3}{*}{ Apologies } & Excuse me? & 7 \\
\hline & I am so sorry & 5 \\
\hline & Tabe' & 6 \\
\hline \multirow[t]{8}{*}{ Fillers } & Well & 79 \\
\hline & I mean & 11 \\
\hline & aaa & 130 \\
\hline & yeah & 16 \\
\hline & $\mathrm{hmm}$ & 120 \\
\hline & $e e$ & 280 \\
\hline & so & 189 \\
\hline & As we know & 9 \\
\hline Vernacular & $d i$ & 7 \\
\hline Language & $m i$ & 11 \\
\hline
\end{tabular}

The strength of the article, we can find new vocabulary from the research of the use of politeness strategies in the classroom context by English university students, the explanations given are clear and concise, accompanied by accurate data sources. Then the article raises trivial problems, but has a significant impact if that happens, and includes many references in his research. Findings from this study found that strategies can be seen in the forms of greetings, thanks, address terms, apologies, fillers, and vernacular language.

This finding also shows that students adopted several terms from their language to communicate. Different expressions of politeness are also found in the context of English classes. All of the findings of this study confirm that politeness is essential in EFL classroom interaction. Therefore, several strategies can be used by English students in Indonesia to contribute to effective EFL classroom interactions.

As a final note, the only weaknesses found in the article are the presence of incorrect spellings. These are in minority though, and do not affect the way the authors and other readers in understanding what Mahmud (2019) conveys in the article.

\section{Conclusion}

It can be concluded that some of Brown \& Levinson's (1987) politeness strategies were used by British students in their presentations about positive politeness and negative politeness. This finding shows that the idea of politeness (Brown \& Levinson, 1987) can be applied in the context of Indonesian EFL classrooms. The conclusions of this study also show that cross-cultural context studies of politeness are needed to examine the influence of culture in practising politeness in the classroom. The practice of politeness by British students in Makassar proved to be influenced by the religious and cultural aspects of the interlocutors. The findings of this study have contributed significantly to the process of teaching English in universities in Makassar.

These findings can also be input for other universities in Indonesia, especially for practitioners of EFL classroom interactions (for example teachers and students) about how they should behave in class to achieve effective ways of interacting in teaching English. The findings from this study are also expected to contribute to the politeness research literature in a particular class context and the Asian context, in general. However, further studies need to be done in terms of the practice of the courtesy of teachers and students who are influenced by factors such as age and gender, especially through the choice of language they will use to communicate.

\section{Acknowledgement}

The research would like to thank the Institute of Research Development and Community Service (LPPM) Unilak for their help during the discussions on how to write the research article. However, they might not agree with all the claims and conclusions in this article review, as they belong to the authors' of this article.

\section{References}

Mahmud, M. (2018). Exploring students' politeness perspectives at the State University of Makassar. Journal of Education and Learning, 12(1), 36-43.

Brown, P., Levinson, S. C., \& Levinson, S. C. (1987). Politeness: Some universals in language usage (Vol. 4). Cambridge university press.

Holtgraves, T., \& Perdew, A. (2016). Politeness and the communication of uncertainty. Cognition, 154, 1-10.

Sukarno, S. (2018). Politeness strategies, linguistic markers and social contexts in delivering requests in Javanese. (Master's Theses). Universitas Jember, Indonesia.

Jiang, X. (2010). A Case Study of Teacher's Politeness in EFL Class. Journal of Language Teaching \& Research, 1(5), 651-655. 
Payne-Woolridge, R. (2010). Classroom behaviour and facework: balancing threats and enhancements. Classroom Discourse, 1(2), 167-180.

Senowarsito, S. (2013). Politeness strategies in teacherstudent interaction in an EFL classroom context. TEFLIN Journal, 24(1), 82-96.

Zander, R. (2013). Ethnography of Polite and Impolite Student Classroom Behavior in the Intensive English Center. Linguistic Portfolios, 2(1), 11.

Bargiela-Chiappini, F. (2003). Face and Politeness: New Insights for old Concepts. Journal of pragmatics, 35(10-11), 1453-1469. 